\title{
ECOSYSTEM DEGRADATION AND ITS IMPLICATIONS ON REGULATING SERVICE
}

\author{
Wanyera Francis ${ }^{1}$, Dr. Mutugi Chira Robert ${ }^{2}$, \\ Dr. Najma Dharani ${ }^{3}$ and Prof. Gichuki Nathaniel ${ }^{4}$ \\ ${ }^{1}$ University of Tourism, Technology and Business studies: Department of Tourism. \\ ${ }^{2}$ University of Nairobi; Department of Biological Sciences. \\ ${ }^{3}$ School of Pure and Applied Sciences, Kenyatta University. \\ ${ }^{4}$ University of Nairobi: Department of Biological Sciences.
}

\section{Cite this article:}

Wanyera F., Mutugi C.R., Najma D., Gichuki N. (2021), Ecosystem Degradation and Its Implications on Regulating Service. African Journal of Environment and Natural Science Research 4(4), 74-87. DOI: 10.52589/AJENSRGCJ3B8YV.

\section{Manuscript History \\ Received: 22 June 2021 \\ Accepted: 14 July 2021 \\ Published: 19 Oct 2021}

Copyright $\odot 2020$ The Author(s). This is an Open Access article distributed under the terms of Creative Commons AttributionNonCommercial-NoDerivatives 4.0 International (CC BY-NC-ND 4.0 ), which permits anyone to share, use, reproduce and redistribute in any medium, provided the original author and source are credited.

\begin{abstract}
The purpose of the study was to determine the link between ecosystem degradation and regulating services. It was observed that as the ecosystem cover area decreased, the regulating services offered by the ecosystem also dwindled. The literature of the study covered the ecosystems and causes of degradation and different regulating services. The study was guided by three objectives and they included; to describe the carbon stock trends in Volcanoes National Park; to ascertain the temperature and rainfall patterns in VNP and to determine the soil erosion rates in and around VNP. The methodology of the study considered descriptive research design that was composed of both quantitative and qualitative approaches. Additionally, primary and secondary data were used. The study population was 52 households from two parishes and the sample of 44 households. The data collection tools were questionnaires and interviews while presentation was by use of figures and tables. The findings indicated that in the past three decades, as the population increased, the forest ecosystem area reduced and this affected the regulation of the amount of carbon stock. Also, the results revealed that the rainfall and temperature patterns fluctuate frequently due to the unregulated accumulated carbon dioxide and carbon in the atmosphere. The findings further showed that the rates of soil erosion increased as deforestation increases which led to increased soil erosion and runoff. As a result of soil erosion and runoff, the soil fertility decreased and it affected the crop harvests. In conclusion ecosystem degradation affected the regulation services which also affected the host community. It was recommended that deforestation should be stopped to improve regulating service.
\end{abstract}

KEYWORDS: Ecosystems, Degradation, Regulating, Services, Effects 


\section{INTRODUCTION AND BACKGROUND}

There is a general consensus that forest ecosystems play a crucial role in the global carbon cycle. It has been argued that forest ecosystems absorb approximately $30 \%$ of the anthropogenic emissions of carbon dioxide from the atmosphere (Percy et al., 2003). As a result, there is an increase in the amount of carbon dioxide in the atmosphere which is estimated to have increased from 280ppm in the pre-industrial period (1750) to $379 \mathrm{ppm}$ in 2005 and is observed to be increasing at $1.5 \mathrm{ppm}$ per year. Globally $19 \%$ of the carbon is stored in the plants and 81 in soil (Wessel et al 2004; IPCC, 2007). This increase is attributed to increase in burning fossil fuels, deforestation and also conversion of forest ecosystems to agricultural land. However, the researchers agreed that one of the biggest sources of carbon dioxide is deforestation primarily in the tropics (Pandey, 2002). Additionally, Wessel et al, (2004) added that when the forest ecosystems are degraded or cleared more carbon dioxide is released in the atmosphere. Also, (IPCC, 2007; Mackey et al 2008) highlighted that in Africa, deforestation accounts for nearly $70 \%$ of total emissions. This was because forests store and release carbon dioxide through natural processes. The forest ecosystems sequester and store more carbon dioxide than any other terrestrial ecosystems and so they act as an important natural "brake" on climate change (Katila and Puustjarvi, 2004). It implies deforestation permanently reduces the earth's capacity to store future carbon emissions. Forest ecosystems act as carbon sinks, absorbing carbon from the atmosphere and storing it in the wood, soil and other organic materials (Percy et al 2003; Tagupa et al. (2010). Further, almost half of the carbon stock in moist tropical forest ecosystems is stored in vegetation which is higher than other biomes (Seymour et al 2002; Keeton et al 2007 and Franklin et al 2002). This points to the fact that forest ecosystems are important carbon pools which continuously exchange carbon dioxide with the atmosphere and so must be conserved to regulate climate change (Pandey, 2002). Finally, carbon stock and storage in natural forest ecosystems seems the only simplest and costeffective method of reducing carbon dioxide accumulation in the atmosphere (Katila and Puustjarvi, 2004). Otherwise, the growing population, rapid industrialization and urban development catalyze deforestation which removes the carbon sinks. This is because it not only helps support humanity but also other natural ecosystems that will keep them healthy and sustainable (Keetn et al., 2007).

Rwanda has experienced forest degradation over years and statistics show that in 1960's the forest area covered 65900 hectares and due to deforestation, the forest cover area has reduced to approximately $64 \%$ from 1960 to 20017 which actually puts it at $1.3 \%$ destruction rate per year (Republic of Rwanda, 2017). The earlier studies attach these events to rapid increase to population which has led to deforestation due to land for settlements, agriculture, grazing cattle. However other threats are attributed to illegal timber production and bush fires. Additionally, human activities observed to threaten forest covers during the forest inventory in 2007 were illegal tree harvesting that accounted for $78.3 \%$ by then, charcoal burning $4.9 \%$, livestock grazing $2.5 \%$, agricultural activities $2.0 \%$, bush fires $1.9 \%$ stem debarking $0.6 \%$ mining $0.5 \%$ and bee keeping $0.4 \%$ (MINISTERE-ISAR, 2007). The study area which happens to be Volcanoes National Park has been under continuous direct and indirect degradation as a result of high rapid population growth due to fertile volcanic soils that have led to food production in the park's vicinity thus creating pressure on forest ecosystems. For example, in 1958 over 700 hectares were cleared mainly for settlement and the period from 1969 to 19731050 hectares were cleared for agricultural activities (ORTPN, 2004; FAO, 2007). 
Horwich and Lyon, (2007) argued that forestry provides several tangible and intangible goods and services in and around Volcanoes National Park which include timber products such as fuel wood, timber, pulp wood and bamboo material, tannins, herbs, spices, insecticides, soap substitutes, dyes, cork and honey. The key services include carbon sequestration, air regulation, soil formation and nutrient cycling, micro climate modification, forest aesthetic appeal modification value as well derived activities such as employment (Miles and Kapos, 2008). Therefore, maintaining forest ecosystems as carbon stores is crucial in carbon management. Similarly, forest management practices such as increased forest growth rates, community involvement in reforestation have been implemented to increase carbon sequestration (Miles and Kapos, 2008; UNFCCC, 2007).

As a result of continuous pressure on land for the last 30 years, there has been high degradation of forest ecosystems. For example Volcanoes National Park has had its size reduced from $328 \mathrm{~km}^{2}$ in 1958 to its current size of $162 \mathrm{~km}^{2}$ (Plumptre, 2004). Refugees and high populations demanded land for settlement, agriculture and grazing and as a result engaged in clearing of forest ecosystems particularly in the park (ORTPN, 2005). Similarly, Horwich and Lyon, (2007) Hulme and Murphee, (2001) argued that the presence of very poor people around the protected area poses a serious threat to the conservation of its natural ecosystems. This threat is coupled with having limited economic alternatives and thus making them more dependent on the forest ecosystems (Plumptre, 2004). Due to such a situation, the destruction and clearance of the forest ecosystem becomes inevitable because the local community are finding ways to improve their survival. Additionally, the poor are the most affected and with the negative perception about the park-forest ecosystems, they end up harvesting the ecosystem goods to supplement on their subsistence farming and hence destroy the forest ecosystems and hence decline in crop harvest (Blomley, 2010). The study objectives were; to describe the ecosystem changes and carbon trends in and around Volcanoes National Park (VNP) ; to determine the regulation services affected by the ecosystem changes in and around VNP

\section{MATERIALS AND METHODS}

The Volcanoes National Park is located on $1^{\circ} 30^{\prime} 5,29^{0}$ 'E or $1^{\circ} 21^{\prime}-1^{\circ} 35^{\prime}$ 'South, $29^{\circ} 22^{\prime}-29^{\circ} 44^{\prime}$ East, and is situated in the Northern province of Rwanda bordering Democratic Republic of Congo (DRC) and Uganda. It covers medium and high altitudes towards the south of the Virunga chain (Plumptre et al., 2004; ORTPN, 2005). Its length is around 40km and its width varies from $8 \mathrm{~km}$ to $1 \mathrm{~km}$ in some parts due to extensive deforestation. The interface of the protected area with its local population is around $60 \mathrm{~km}$ and the park area covers approximately $162 \mathrm{~km}^{2}$ (Plumptre, 2004). The park's altitude ranges from $2400 \mathrm{~m}$ to $4500 \mathrm{~m}$ while the highest elevated point is the top of Karisimbi which is 4507 meters above sea level. It is composed of the volcanoes which include Muhabura, Gahinga, Sabyinyo in the east while Bisoke, and Karisimbi are in the western part. The park lies within the Provinces of Gisenyi $(15 \%)$ and Musanze (85\%) along the border of the DRC and Uganda (Plumptre et al., 2004; ORTPN 2005). 


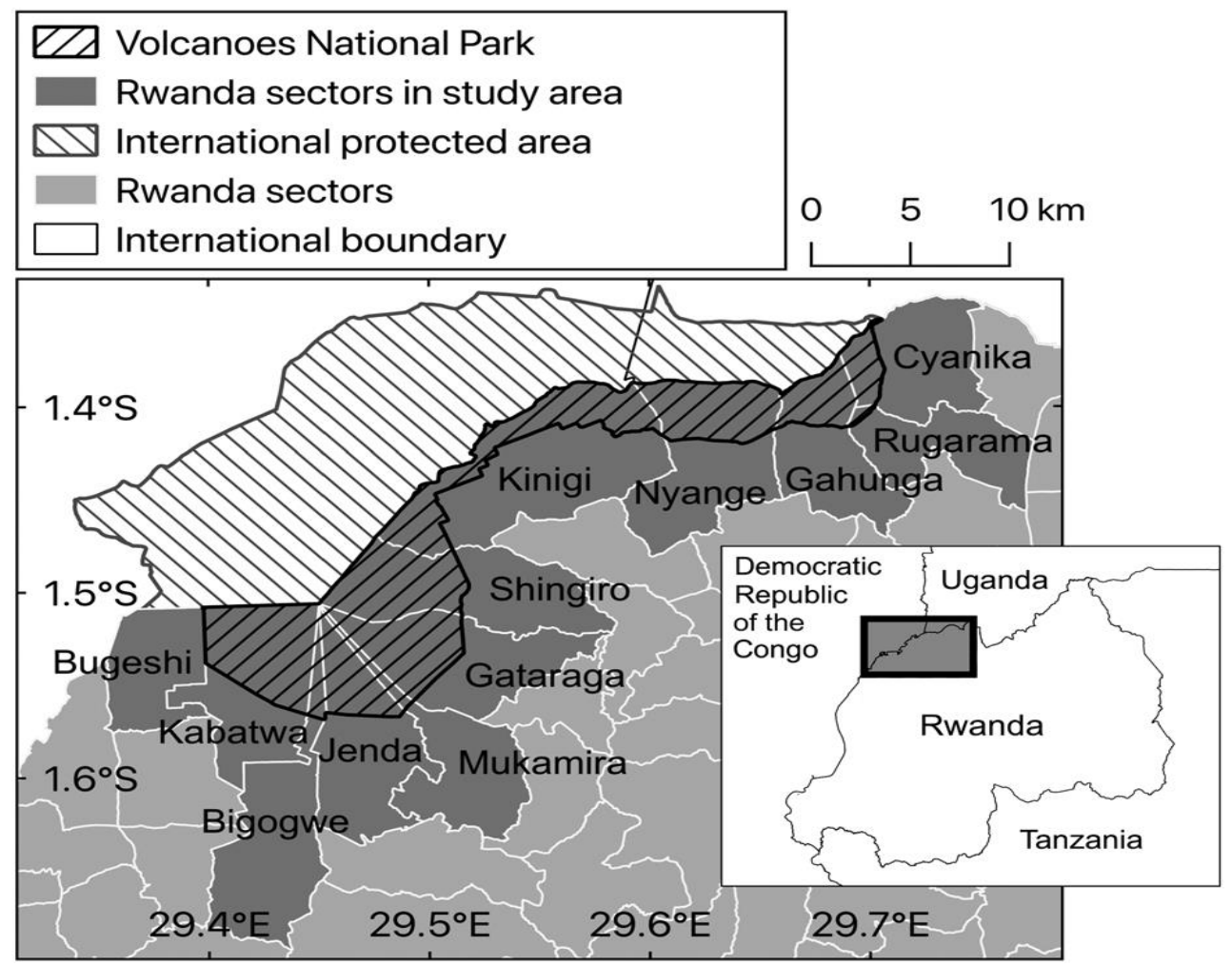

It is surrounded by extremely high population density with an average of 380 persons per $\mathrm{km}^{2}$ with some areas occupied by 820 persons per $\mathrm{km}^{2}$ (Waller, 1996; Lanjouw et al., 2001). The adjacent areas are occupied by more than $90 \%$ of the local community whose main socioeconomic activities involve subsistence farming. With less income and low crop harvests, the majority of local communities end up depending on park resources in one way or another for their livelihood. The majority of the host community has been classified as living in extreme poverty, with over 50\% having no land to meet their basic needs (Lanjouw et al., 2001).

The study area majorly experiences tropical climate. The Volcanoes National Park area experiences annual temperature ranging from a minimum of $7-15^{0} \mathrm{C}$ to a maximum of $20-27^{0}$ C. The annual rainfall patterns range from 1400 millimeters to 1900 millimeters (Plumptre et al., 2004). Volcanoes National Park area and adjacent districts are highly populated. Population density is influenced by the rich volcanic soils, natural population growth, and reduced mortality rates. The protected area is located in one of the most heavily settled and poorest communities in the region. Unfortunately, the scarcity of land is crucial because the limited land hinders them from increasing their prosperity through agriculture (ORTPN, 2005). Districts around the park have a total of 479,330 to 800,678 persons, resulting in increasing pressure on the natural capital (MINICOM, 2014). Similarly, districts around VNP, have higher population density, with an average of 690 persons per $\mathrm{km}^{2}$ (ORTPN, 2005, RDB, 2014). This population exerts a lot of stress on the natural resources majorly through agriculture and harvesting fuel wood (Plumptre et al., 2004).

The target population was 150 households in four cells and yielded 48 households as a sample. Sampling process was made possible with the help of community guides, park managers and a community leader who had wide working experience to harmonize people-park relations. 
Purposive sampling technique and stratified sampling was used in this study. Anthropogenic activities assessment was conducted inside and outside the protected area boundary. A map of the park boundary and surrounding parishes was used with the help of handheld global positioning system (GPS). All visible evidence of human activities were recorded. Boundary walls covered the purposely selected park areas heavily impacted by human activities. Walking along the boundary line, was to take note of encroachment activities, evidence of resource harvesting, and other anthropogenic disturbances, including agricultural encroachment, timber, fuel wood harvest and construction material harvesting were observed and recorded.

The surveys were carried out in the period of 30 days from $1^{\text {st }}$ July 2018 to $30^{\text {th }}$ July 2018 . For efficient data collection, 3 days were spent in each of these selected sites to have ample time to interact with the respondents (local communities), to get their opinions about; anthropogenic activities, and how they impact on ecosystems. The research team consisted of a park guide, community guide, a local leader and a researcher. The unit of measurement was the household and each household contributed two respondents. These were the two leaders in a household and were mother and father or two adults. All these were purposely sampled together with the park staff as well as the local authorities and placed them in strata. Anthropogenic activities were recorded from respondents, deforestation trends, ecological changes and other human activities such as agriculture, settlements, grazing that influence ecosystem changes. Signs of anthropogenic activities were recorded within a distance of about $300 \mathrm{~m}$ of the boundary. This was because earlier studies by (Olupot, 2009) indicated that most resource use was harvested by locals within 300 meters of the park boundary. The population of the study was 40 households from two cells that included nyabigoma and Nyoririma and the study used 34 households as the sample

The human activity indicators recorded included cutting of trees, fuel wood, timber, handcraft plants, medicinal plants and construction materials. Also grazing, settlements, cut vegetation, and agriculture. To investigate these anthropogenic activities, 4 discussion groups were organized. Key informant interviews targeted 5 respondents were carried out. Key informant interviews were majorly conducted in English with park staff and local leaders but group discussions were conducted in local languages. In and around the study area it was Kinyarwanda which is also the language used by participants. The exercises were conducted in the local language by the local leaders and community guides who were well conversant with the language. These methods were in agreement with Savin-Baden and Major (2012) who pointed out that key informant and group discussion methods can be used concurrently in order to support and fill the gaps of either method. The housing and population census 2012 list was the sampling frame.

To estimate the biomass in forest ecosystems, the IPCC Tier! methodology was used (IPCC,2003). This was applied to the standing volume (cubic meters and since carbon is reported as weight tonnes, the standing volume estimates have to be converted. In this case, the standing timber volume is converted to weight (KG (using a biomass conversion expansion factor (BCEF) appropriate for the climate zone and forest type (equation 1)

\section{Above Ground Biomass I $(\mathrm{ABG})=\mathrm{M}^{3} * \mathrm{BCEF}_{\mathrm{s}}^{\mathrm{i}}$}

Where I indexes the growing stock level and BCEF is the Biomass Conversion Expansion Factor. Below Ground Biomass or Root Biomass Dry Matter (RDBM) is calculated using an equation that converts aboveground biomass to RBDM 
$\left.\mathrm{RDBM}=\mathrm{e}^{(-1.805+0.9256+\operatorname{In}(\mathrm{AGBi})}\right)$

Where AGB is the Above Ground Biomass for growing stock level I. When the biomass of standing volume of timber is converted to weight, then the weight of carbon is determined by assuming that biomass weight is 49\% (IPCC, 2003). The total carbon sequestered per hectare is calculated as below

$\mathrm{C}$ (tonnes) $=(\mathrm{AGB}+\mathrm{RBDB}) \times 0.49$

Where 0.49 is the conversion factor of tonnes of dry matter to carbon (IPCC, 2003

\section{RESULTS}

Results in Figure 1, disclosed that Volcanoes National Park experienced changes in forest area during the same period. The baseline year of 1960 was also used and results revealed that total forest area was 34000 but by 1970 it had reduced by 52.94\%. This was also attributed to an increase in population that created demand for agricultural land, fuel wood, timber, settlement and grazing land. Similarly, the period between 1970 to 1980, indicated that the forest area reduced further by a smaller rate of $6.25 \%$ as compared to the period between 1980 to 1990 which reduced by a big rate of 14.93\%. However, between 1990 and 2000 there was no data to indicate change. This was as a result of continued demand for fuel wood, timber, and agricultural land which resulted in over exploitation of forest ecosystems. It was the period when there was civil war and genocide and so no data was recorded. Interestingly from 2000 to 2010 the forest area continued to reduce by a rate of $5.96 \%$ and was attributed to demand for land to cultivate by the returning refugees and displaced people. Results further indicated that from 2012 till 2015, the forest area gradually increased at a higher rate compared to population as a result of alternative energy sources such as biogas and incomes. The trend in both results (Figure $25 \& 26$ ) revealed that as population increased the forest areas in unprotected land and protected areas reduced, it clarified the increased demand for fuel wood and timber products by adjacent local communities. This was clearly indicated in Figure 1 how the percentage of forest area dwindled with time as population grew.

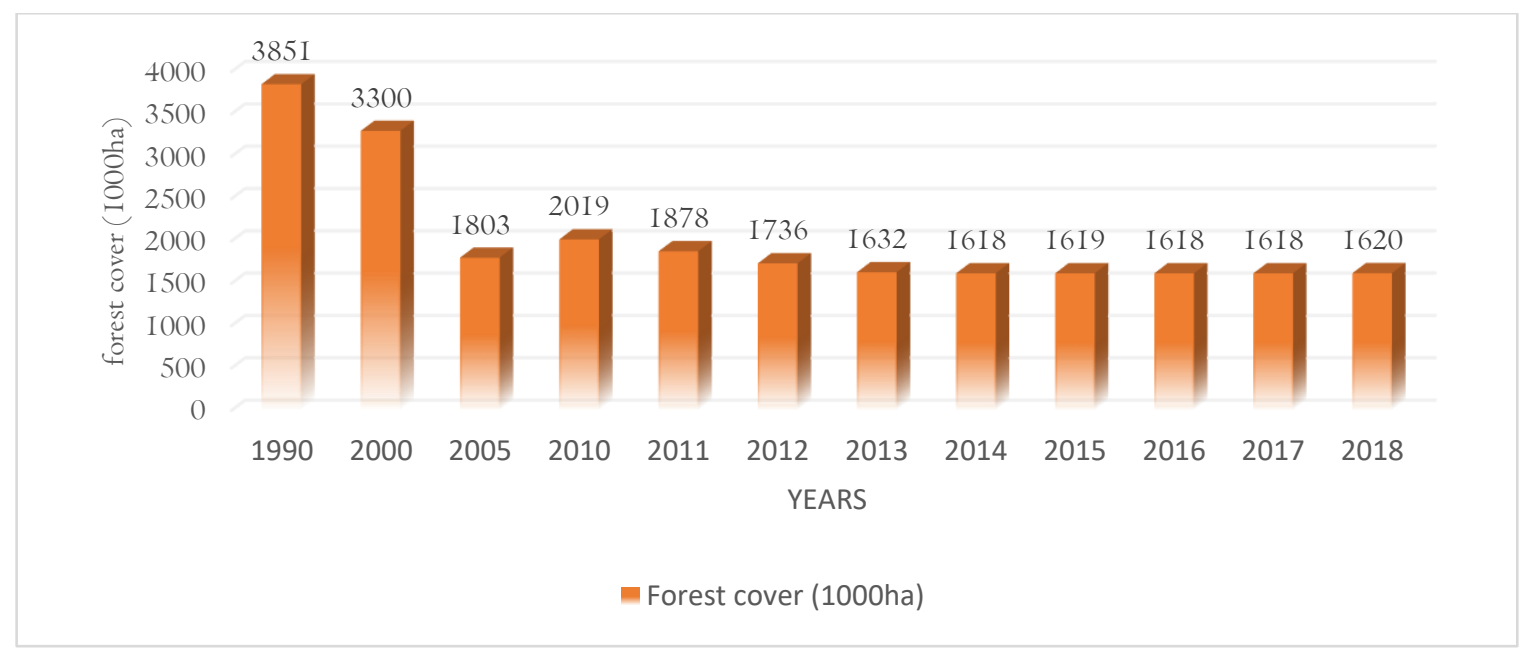


Taking 1990 as a baseline year, the results revealed that population density in the entire country increased at an average rate of $3 \%$ per annum. In the study area, the population growth rate was high at $3.5 \%$ which resulted in high population pressure on the protected area forest ecosystems. In figure 2, the period from 1990 to 2000 the carbon stock dropped from 5.4 metric tons to 5.1 metric tons in 2000 and the decline was by $0.3 \%$ and at the same time the forest area decreased by approximately 350 hectares. This was attributed to demand for agricultural land, grazing land and settlement which led to intensive ecosystem clearance. This was linked to continued demand for fuel wood, timber, and agricultural land which resulted in clearance of forests. Whereas the period between 1990 and 2000 saw the increase in population per square kilometer grew once again by $6.68 \%$ but the forest area reduced further by $15 \%$. This was however, different from the period between 2000 and 2015 where, the carbon stock increased by $23.5 \%$ but forest area reduced by $12.16 \%$. This was due to increased laws for protection and planting more trees and woodlots in the adjacent areas. Conversely the period from 2015 to 2020 the carbon stock dropped from 6.3 to 5.9 metric tons which dwindled and was represented by $6.3 \%$.. The trend in results indicated that as population density increased, more of the forest cover dwindled as well as decline in carbon stock (Figure 2).

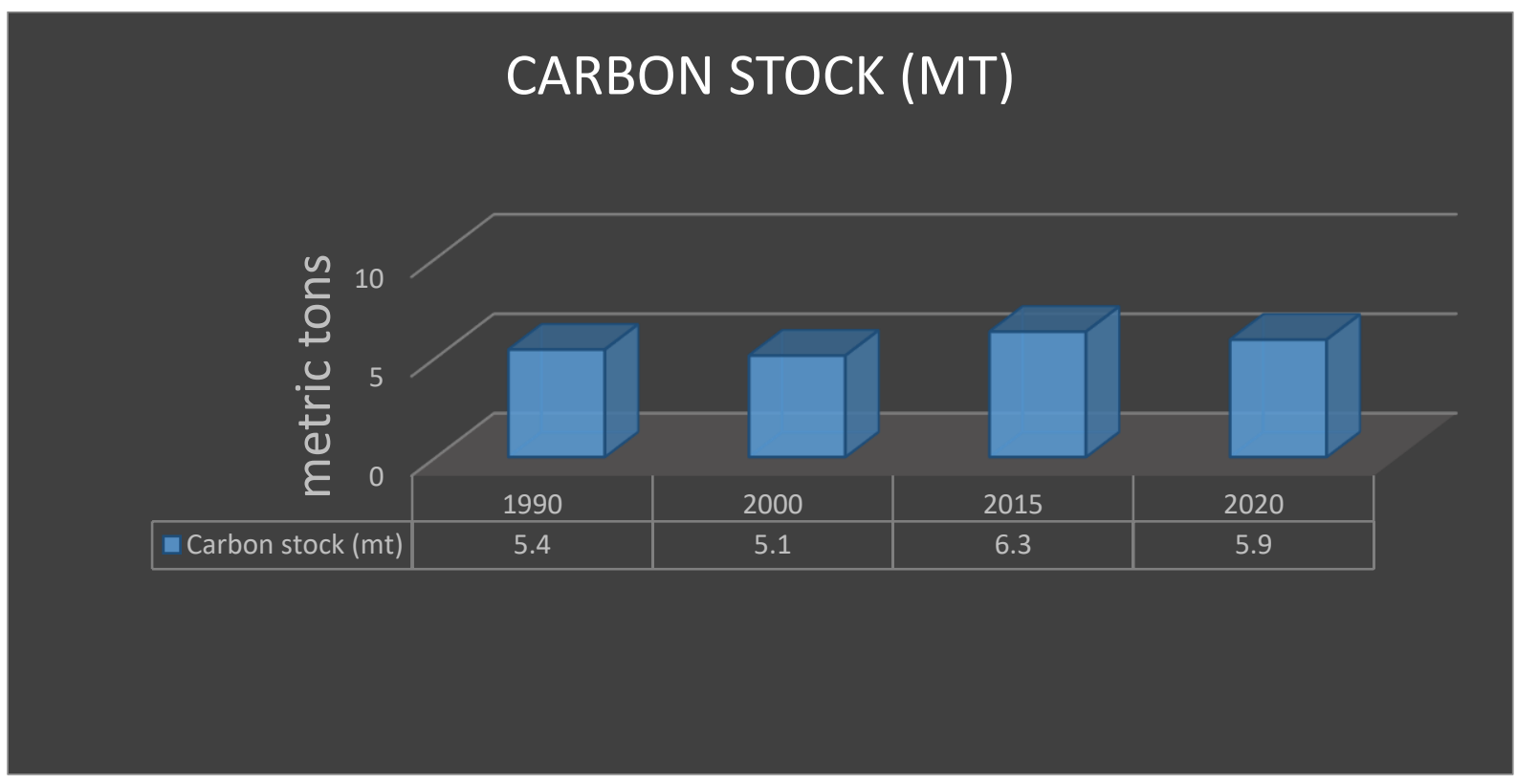

Figure 2: Carbon stock in plants and soil in VNP (base year 1990-2020)

Results in Figure 3, indicated that climatic variations have occurred over the last two decades. According to the Key Informants, they revealed that rainfall and temperature patterns fluctuated but with high spikes notably in rainfall. This was attributed to deforestation that disrupted the rainfall patterns as well increased temperature due to greenhouse effects as a result of carbon in the atmosphere. The data indicated that average rainfall from January continued to increase and hit the highest amount in the month of April. Thereafter the results showed that the rainfall pattern declined until the month of July due to increased deforestation and carbon stock. Which indicated the increased temperature and less precipitation. However, 
the key informants argued that from the month of August, the results indicated increased average precipitation recorded and this continued up to the month of November and this because of the most wind from the evapotranspiration due to increased warm temperature around the forest ecosystem. On the other hand, the key informant emphasized that the temperature patterns indicated that there was an increase by one degree centigrade in the maximum data. Similarly, the minimum temperature slightly increased from January to May and dropped in the months of June and July due to carbon in the atmosphere. From the month of August, the temperature increased progressively until October, declined again in November but in December it increased.

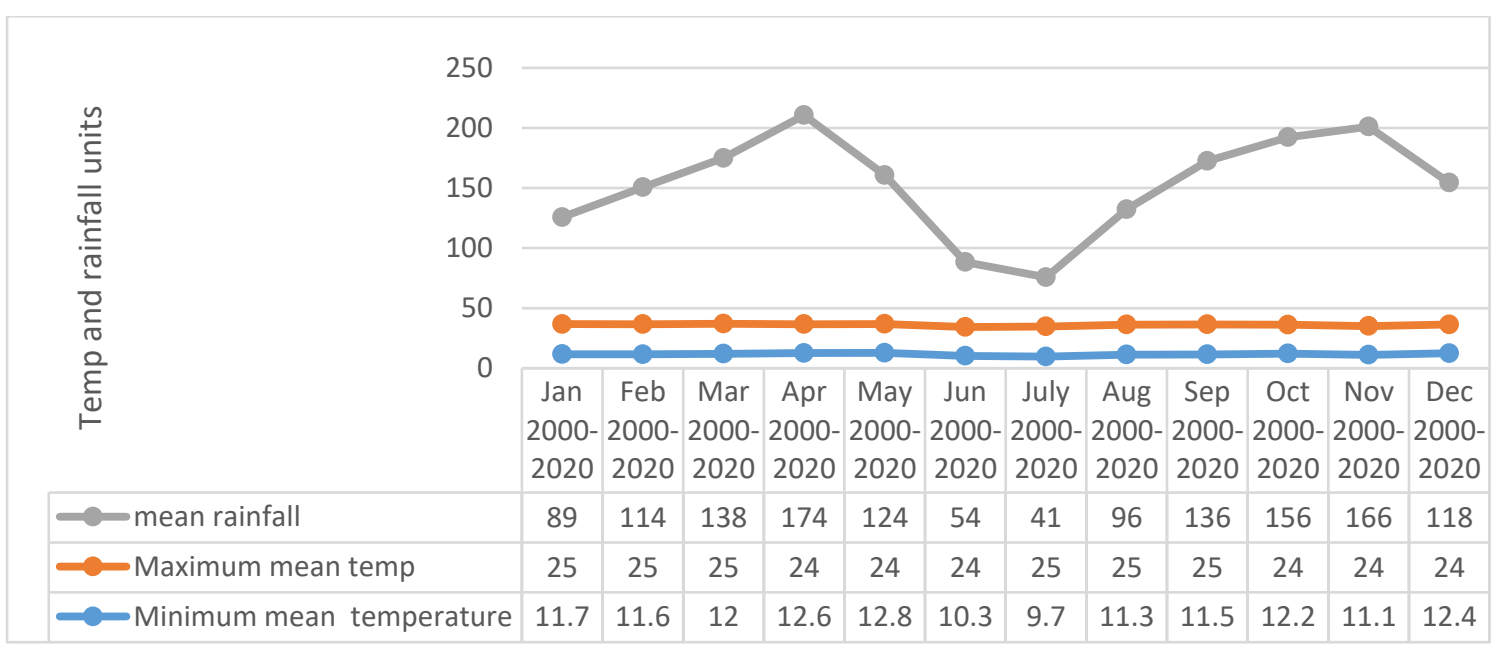

Figure 3: Rainfall and Temperature patterns in and around VNP 2019

The results in Table 1, about the soil erosion indicated that as a result of short heavy showers and deforested areas around the park experience high rates of soil erosion. It can be observed that the district of Gakenke with a crop coverage rate of $65 \%$ was the most affected followed by the district of Musanze with 59\%. According to the Key informant. This was attributed to rampant deforestation as a result of high population which cleared the vegetation for agriculture, grazing and settlement. The key informant argued that as a result of intense agriculture, it led to high erosion rates and runoff. From Table 1 it was observed that the higher the crop coverage the more that erosion rates. This showed the link between the crop area and the amount tons of soil eroded. For instance, it was revealed that Gakenke with the largest crop area was the one with the highest amount of soil in tons eroded as compared to Rubavu with lowest crop area. Respondents in Focus Group Discussion (FGD) agreed that there was extensive deforestation around the park and as a result they experienced floods, soil erosion and frequent run off during rainy periods. In addition, the Key informant highlighted that the steepness of the landscape also played a crucial role in amount of soil eroded and rate of erosion as indicated in Table 1 below. 
Table 1: Soil erosion challenge around Volcanoes National Park

\begin{tabular}{|l|l|l|l|l|l|}
\hline $\begin{array}{l}\text { District } \\
\text { adjacent to } \\
\text { VNP }\end{array}$ & $\begin{array}{l}\text { Soil erosion } \\
\text { rate (tons/ha) }\end{array}$ & $\begin{array}{l}\text { Contribution to } \\
\text { national soil } \\
\text { erosion \% }\end{array}$ & $\begin{array}{l}\text { Area } \\
\left(10^{3} \mathrm{~km}\right)\end{array}$ & $\begin{array}{l}\text { Cropland } \\
\text { coverage } \\
\%\end{array}$ & $\begin{array}{l}\text { unsuitable } \\
\text { cropland } \\
\%\end{array}$ \\
\hline Burera & 413 & 4.1 & 59 & 54 & 2.9 \\
\hline Musanze & 244 & 2.1 & 51 & 59 & 1.6 \\
\hline Rubavu & 176 & 1 & 34 & 48 & 0.8 \\
\hline Rulindo & 500 & 4.8 & 57 & 52 & 2.7 \\
\hline Gakenke & 678 & 8 & 70 & 65 & 6.5 \\
\hline
\end{tabular}

Source: field, 2019

According to focus group discussion, the respondents agreed that there was decline in crop yields. The results in Table 2, indicated that from 2007 as a base year, there has been a general decline in harvest amongst the majority of the crops cultivated in the adjacent areas. The focus group discussion groups highlighted that the decline in crop harvests was due to high rates of erosion and run off during the rainy periods that had led to decline in soil fertility. In the same way the key informants also argued that they don't have enough to eat as a result of unpredictable rains and abrupt flush floods that erode away their crops and thus shortage of food supply. Results in Table 2 also indicated that for example maize and wheat in 2018 and 2019 experienced decline in crop yields and this was attributed to sporadic rainfall patterns and reduced soil fertility. Additionally, the findings in Table 2 revealed that Irish potatoes, sweet potatoes and vegetables were among the main food crops that recorded dropped harvests. The key informants argued that poor soils coupled with unpredictable rainfall were the cause. Similarly, the focus group discussions emphasized that all these were attributed to lack of enough land for cultivation. Majority agreed that due to poverty, they had no resources to afford more land for cultivation, so this had led to less harvests and decline in yields due to intensive agriculture on small parcels of land they owned. The little harvests were reflected in Table 2 below

\section{Table 2}

\begin{tabular}{|l|l|l|l|l|l|l|l|l|l|l|l|l|}
\hline $\begin{array}{l}\text { Food crop } \\
\text { (metric tons) }\end{array}$ & 2007 & 2009 & 2010 & 2011 & 2012 & 2013 & 2014 & 2015 & 2016 & 2017 & 2018 & 2019 \\
\hline Sorghum & 14 & 20 & 13 & 8 & 16 & 20 & 16 & 18 & 14 & 17 & 16 & 15 \\
\hline Maize & 74 & 217 & 66 & 341 & 317 & 321 & 312 & 319 & 309 & 311 & 307 & 266 \\
\hline Wheat & 11 & 38 & 9 & 27 & 35 & 38 & 38 & 36 & 37 & 38 & 26 & 30 \\
\hline Paddy & 29 & 56 & 28 & 33 & 59 & 57 & 55 & 56 & 58 & 55 & 46 & 53 \\
\hline Beans & 195 & 187 & 120 & 179 & 196 & 197 & 183 & 188 & 185 & 196 & 183 & 190 \\
\hline Peas & 13 & 16 & 8 & 12 & 17 & 15 & 16 & 18 & 17 & 16 & 18 & 15 \\
\hline Vegetable & 457 & 511 & 417 & 552 & 518 & 521 & 511 & 516 & 512 & 529 & 415 & 405 \\
\hline Soya & 34 & 32 & 12 & 13 & 35 & 30 & 34 & 37 & 32 & 30 & 35 & 29 \\
\hline Ground nuts & 6 & 6 & 6 & 6 & 6 & 6 & 6 & 6 & 5 & 6 & 7 & 6 \\
\hline
\end{tabular}




\begin{tabular}{|l|l|l|l|l|l|l|l|l|l|l|l|l|}
\hline Sweet potatoes & 296 & 332 & 317 & 283 & 334 & 338 & 332 & 335 & 289 & 334 & 332 & 312 \\
\hline Irish potatoes & 374 & 822 & 759 & 1113 & 1225 & 1218 & 1326 & 1322 & 1322 & 1318 & 1277 & 1219 \\
\hline Taro & 83 & 77 & 75 & 67 & 78 & 77 & 77 & 77 & 75 & 77 & 76 & 76 \\
\hline Cassava & 403 & 818 & 416 & 1124 & 1119 & 1218 & 818 & 818 & 817 & 818 & 802 & 819 \\
\hline Bananas & 1307 & 1651 & 1187 & 1483 & 1551 & 1653 & 1651 & 1651 & 1650 & 1651 & 1554 & 1488 \\
\hline
\end{tabular}

Source: Field 2019

\section{DISCUSSION}

Under this section, the researcher discussed the findings in relation to the earlier study carried out. From the findings the discussion was based on the specific objectives of the study. The results indicated that as a result of high population pressure, there was increased deforestation. Due to the high rate of deforestation, considering 1990 as a base year, the forest cover progressively dwindled. As a result of forest degradation, the regulating service offered by the forest was reduced. This was attributed to reduced capacity of carbon sequestration and so the carbon stock dwindled as the forest cover area also dwindled. The findings were in agreement with authors such as researchers who agreed that one of the biggest sources of carbon dioxide is deforestation primarily in the tropics (Pandey, 2002). Additionally, Wessel et al, (2004) added that when the forest ecosystems are degraded or cleared more carbon dioxide is released in the atmosphere. Also, FAO, 2001, FAO, 2005; UNEP, 2002 highlighted that in Africa, deforestation accounts for nearly $70 \%$ of total emissions. Also, earlier studies agreed that forest ecosystems play a role in greenhouse regulation and also requires better understanding of the carbon cycle at the forest level. Globally $19 \%$ of the carbon is stored in the plants and $81 \%$ in soil. While in the tropics approximately $50 \%$ of the carbon is stored in the plants and $50 \%$ in soil (IPCC, 2007; Mackey et al 2008).

In the same line, the results indicated that due to deforestation, there was increased climatic variation. These variations were reflected in the erratic rainfall and temperature patterns. The presence of carbon emissions and reduced forest cover, also led to reduced carbon absorption and thus creating greenhouse effect which results in increased temperature and unpredictable rainfall patterns. These results were in agreement with the earlier studies done by the authors such as Percy et al 2003 who agreed that forest ecosystems regulated carbon dioxide since they act as carbon sinks, absorbing carbon from the atmosphere and storing it in the wood, soil and other organic materials. Additionally understanding the role forest ecosystems play in greenhouse regulation also requires better understanding of the carbon cycle at the forest level. Additionally, the forest ecosystems regulate, sequester and store more carbon dioxide than any other terrestrial ecosystems and so they act as an important natural "brake" on climate change. They do that through a process of removing carbon dioxide from the atmosphere and storing it in plants that use sunlight energy to convert carbon dioxide into biomass and oxygen (Tagupa et al 2010).

Finally, the results indicated that deforestation, settlement and majorly agriculture led to high rates of soil erosion, soil degradation as well as the decline in crop harvests. The findings showed that ecosystem degradation and vegetation clearance on steep hills accelerated soil runoff and soil fertility decline. The decline in soil fertility led to decline in food crop yields which affected the sustenance of the local community adjacent to the park. The results were in 
agreement with earlier studies carried out by researchers that highlighted that human activities observed to threaten forest covers during the forest inventory in 2007 were illegal tree harvesting that accounted for $78.3 \%$ by then, charcoal burning $4.9 \%$, livestock grazing $2.5 \%$, agricultural activities $2.0 \%$, bush fires $1.9 \%$ stem debarking $0.6 \%$ mining $0.5 \%$ and bee keeping 0.4\% (MINISTERE-ISAR, 2007). Further, continuous direct and indirect degradation as a result of high rapid population growth due to fertile volcanic soils that have led to food production in the park's vicinity thus created pressure on forest ecosystems. For example, in 1958 over 700 hectares were cleared mainly for settlement and the period from 1969 to present approximately 1050 hectares were cleared for agricultural activities (ORTPN, 2004; FAO,2007).

\section{CONCLUSION}

The purpose of the study was to describe the situation of ecosystem degradation and its effect on the regulating service in and around Volcanoes National Park. Based on the findings, it was concluded that forest and soil ecosystems had the capacity of storing carbon but degradation of the ecosystems affected the regulating service and the study found out that carbon stock dwindled as the ecosystem size reduced. It was therefore concluded that the more the ecosystems degraded, the more they offered less regulating services and thus led to greenhouse gas effects composed mainly of carbon. Conclusively the reduction in carbon stock led to accumulation of carbon-dioxide in the atmosphere and this caused increased temperatures as well infrequent rainfall patterns. It was also concluded that deforestation by the local community impacted negatively on the amount of carbon stock in forest ecosystems and soil ecosystems. From the results also it was concluded that soil erosion regulating service also dwindled as the forest cover area reduced since ecosystems played a carbon sink function. This led to increased runoff which directly affected the soil fertility. As the soil fertility declined, the crop yields in the adjacent agricultural farms reduced which negatively impacted on the livelihood of the local community. Finally, it was concluded that the regulating service of the ecosystems in and around the park had declined due to deforestation and high rates of erosion as a result of vegetation clearance which affected the ecosystem efficiency in carbon storage which also affected the health and welfare of the local community.

\section{RECOMMENDATIONS}

$>$ It was recommended that the government in conjunction with the other stakeholders should encourage tree planting projects amongst the local community surrounding the park to increase on the carbon sink

$>$ The park and government should create awareness amongst the adjacent local community so that they may practice better agricultural practices that will not degrade soils to reduce the amount of carbon stock in the soil ecosystems.

$>$ The local community should be involved in park forest ecosystem management as well as the government implementing the rules, laws and policies in line with ecosystem protection, use, sustainability as well as wellbeing of the local community 


\section{REFERENCES}

Bonan G. B. (2008). Forests and climate change: forcings, feedbacks, and the climate benefits of forests. Science, 320:1444-1449. Born, Germany. Cambridge, M. A, Cambridge University Press.996 p.

Collins, S. Larry, B. (2008). Caring for our natural assets : an ecosystems services perspective. In :Deal, R. L., ed. Integrated restoration of forested ecosystems to achieve multi-resource benefits: proceedings of the 2007 National Silviculture Workshop.Gen.Tech.Rep.PNW-GTR-733.Portland,OR:U.S. Department of Agriculture,Pacific Northwest Research Station :1-11, Cycles,Sequestration, and Storage http://iufro.boku.ac.at/iufro/taskforce/hptfcs.htm NewsletterNo.1. Degradation: a synthesis report for REDD+ policymakers. Vancouver, Canada

Dey, S. K. (2005). A preliminary estimation of carbon stock sequestered through rubber (Havea brasiliensis) plantation in North-Eastern region of India. Indian Forester,131 (11):1429-1436

Ndomba, D, Nkuutu, PSsegawa \& G.Eilu (2004). The biodiversity of the Albertine Rift .Albertine Rift Technical Reports,3,105. ed on February 6, 2007

Elias ,P.E., and D. Boucher. (2010). Financing ambitious REDD+goals.Side event presentation at the $32^{\text {nd }}$ Meeting of UNFCCC Subsidiary Bodies.Bonn,Germany.

Elias, P.E., and D. Boucher. (2010) Financing ambitious REDD+ goals. Side Environmental Pollution 116:S17-S24.

Food and Agricultural Organization (FAO) (2005). Global Forest Resource Assessment 2005. FAO Rome Paper 147. Event presentation at the $32^{\text {nd }}$ Meeting of UNFCC Subsidiary Bodies Oxford University Press,Oxford.403

FAO, (2001). Forest resources assessment 2000,Main report.FAO Forestry Paper 140,Rome,479 pp for Policymakers .

A Franklin, J. F., T. A Spies, R. Van Pelt B. Carey, D. A. Thornburgh, D. R. Berg, D. B. Lindenmayer, M. E. Harmon, W. S. Keeton, D. C. Shaw, K. Bible , and J.Q. Chen. (2002). Disturbances and structural development of natural forest ecosystems with silvicultural implications, using Douglasfir as an example. Forest Ecology and Management 155:399-423

Frumhoff, P. C., J. J. McCarthy, J. M. Melillo, S. C. Moser, and D. J. Wuebbles. (2007) Confronting Climate Change in the U.S Northeast: Science, Impacts and Solutions. Northeast Climate Impacts Assessment. Union of Concerned Scientists,

http:news.bbc.co.uk/2/shared/bsp/hi/pdfs/02 0207 climatereport.pdf(Accessed on February 6,2007) http;//news.bbc.co.uk/2/shared/bsp/hi/pdfs/02 0207 climatereport.pdf Access

Hurteau, M., North, M. (2009). Fuel treatment effects on tree-based forest carbon storage and emissions under emissions under modeled wildfire scenarios. Frontiers in Ecology and the Environment. 7(8): 409-414. Impacts, on ecosystems or different level of climate change Global Environ change.,

Intergovernmental Panel on Climate Change (IPCC), (2000) Land Use, Land-Use Change, and Forestry, Cambridge University Press, New York,pp.1-20

Intergovernmental Panel on Climate Change (IPCC).2007. Climate change 2007: the physical science basis. Contribution of Working Group 1 to the Fourth Assessment Report of the Intergovernmental Panel on Climate Change. New York:

IPCC, (2007) Climate Change 2007: The Physical Science Basis. Summary IPCC, (2007) Climate Change 2007: The Physical Science Basis. Summary for policymakers, 
IPCC. (2001) Climate Change 2001: Working Group I: The Scientific Basic. Cambridge University Press,New York.

Keeton,W.S,.C.E. Kraft,and D.R Warren (2007).Mature and old-growth riparian forests: Structure,dynamics, and effects on Adirondack stream habitats. Ecological Applications 17:852-868.

Kissinger, G., Herold, M. \& de Sy , V . (2012) . Drivers of deforestation and forest: A synthesis report for REDD+ policy makers. Vancouver Canada, Luxeme Consulting

Leemans, R. and B Eickhout (2004). Another reason for concern: regional and global impacts on ecosystems or different levels of climate change. Global environ change: 14: 219-220

Luyssaert,S.,E.D.Schulze,A.Borner,A.Knohl,D.Hessenmoller,B.E.Law, P.Ciais,and J.Grace. (2008) Old-growth forests as global carbon sinks.

Mackey B.G et al.. (2008). Green Carbon:The Role of Natural Forests in Carbon Storage,Part 1,A Green Carbon Account of Australia's South-Eastern Eucalypt Forests ,and Policy Implication ,The Fenner School of Environment \&Society, The Australian National University,Canberra,Australia,2008

Mackey B.G.et al., (2008). Green Carbon: The Role of Natural Forests in Carbon Storage, Part 1,A Green Carbon Account of Australia's South-Eastern Eucalypt Forests, and Policy Implications. The Fenner School of Environment \&Society, The Australian National University,Canberra,Australia.

McNulty,S.G. (2002). Hurricane impacts on US forest carbon sequestration. Environmental Pollution. 116 S17-S24.

Miles, L \& Kapos, V . (2008). Reducing greenhouse gas emissions from deforestation Nature 455:213-2015.doi:10.1038/nature 07276.

Niles, J. O., S. Brown, J. Pretty, A. S. Ball,and J.Fay. (2002). Potential carbon mitigation and income in developing countries from changes in use and management of agricultural and forest lands. Philosophical Transactions. Series A,Mathematical,Physical, and Engineering Sciences 360:1621-1639.doi:10.1098/rsta.2002.1023.

ORTPN (2007). Plan d ' améManagement de Gestion du Parc National des Volcans. Draft

Owiunji, I., Plumptre, A. J., M. Behangana, T. Davenport, C. Kahindo, R. Kityo, Pandey ,D.N.(2002). Global climate change and carbon management in multifunctional forest .Curr,Sci.,83(5):593602. Paris (Online)

Pavageau, C., Butterfield, R.,\& Tiani, A.M (2013).Current vulnerability in the Virunga landscape,Rwanda.Center for International Forestry Research (CIFOR),Bogor, Indonesia.

Percy, K.E.,Jandl,R.,Hall,J.P.and Lavigne M. (2003) The Role of Forests in Carbon Cycles ,Sequestration and storage http://iufro.boku.ac.at/iufro/taskforce/hptfcs.htm Newsletter No.1

Percy, K. E.,Jandl,R.,Hall,J.P.and Lavigne M.(2003)The Role of Forests in Carbon.

Rwanda Development Board (2013.Annual Report.2012 year and achievements. Kigali Rwanda

Seymour, R. S., A. S. White , and P.G .de Maynadier (2002)Natural disturbance regimes in northeastern North America-evaluating silvicultural systems using natural scales and frequencies. Forest Ecology and Management 155:357-367

Tagupa 1,C.,A.Lopez,A.,Caperida,F.,Pamunag,G.and Luzada A.(2010).Carbon dioxide ( $\left.\mathrm{co}_{2}\right)$ sequestration capacity of Tampilisan forest. E-International scientific research journal. ISSN:2094-1749 volume: 2 issue: 3,2010 
UNEP (2002).Africa environment outlook. Past, present and future perspectives. Earthprint Limited,England,p.422.

United Nations Framework Convention on Climate Change (UNFCCC) (2007).Kyoto Protocol: status of ratification.(online). Available: http://unfcc.int/Kyoto protocol/status-of ratification/items /2613.php (December 14,2009).

Verchot ,L.V.,E.Petkova,K.Obidzinski,S.Atmadja,E.L.Yuliani,A.Dermawan,D.Murdiyarso , and S. Amira. (2010). Reducing forestry emissions in Indonesia .Bogor,Indonesia:CIFOR.

Wertz Kanounnikoff (2009). Realising REDD+: + National strategy and policy options. Bogor, Indonesia.

Wessel W. W, Tietema A, Beier C, Emmett B A, Penuelas J, Riis-Nielsen T(2004). A qualitative ecosystem assessment for different shrublands in Western Europe under impact of climate change using the results of the CLIMOOR research project. cosystems,7:662671.DOI:10.1007/s10021-004-0219- Zone. FAO, Rome, Italy 